\title{
Research on the Problems of Teaching Management in Colleges and Universities
}

\author{
Lixin Fan \\ School of Humanities, Jilin Agricultural University, Changchun 130118, China \\ 897146503@qq.com
}

\begin{abstract}
The teaching management work is an important part of school teaching work. It is the essential guarantee for safeguarding the normal order of the school and improving the quality of teaching. Moreover, the level of teaching quality also determines the level of the personnel training quality of the school, which is related to the survival and development of the school. This paper, taking the education science theory and modern management theory as a guidance, analyzes present situation and the main problems of teaching management exist in ordinary Colleges and universities in the present stage. Combined with the actual situation, establish and perfect a set of scientific teaching management strategy, improve the quality of teaching, and cultivate talents adapt to the demand of social and economic development.
\end{abstract}

Keywords: Teaching management; Talents cultivation; Strategies.

\section{Introduction}

The main task of higher education is to cultivate advanced talents with innovative spirit and practical ability, and the cultivation of talents must be realized through teaching activities. Teaching management work, as the core of the management of Colleges and universities, is an important guarantee for the cultivating quality of College personnel. In the current era of knowledge economy, it has become an inevitable requirement of the society for higher education to cultivate talents with innovative spirit and practical ability. At present, from the analysis of the domestic and foreign present situation of teaching management, most of the teaching managements pay attention to emphasize science, standardization, humanity and so on. It achieves practice and exploration in different degrees of attention and study, from which obtains some research achievements. But for our country, attention paid to the teaching management work started relatively late, and there are still some gaps compared with developed countries. It requires that in the teaching and management work, it is necessary to continue to combine the domestic and foreign advanced management thoughts and reform research, explore and research a high quality teaching management road in line with its own features.

\section{Problems in College Teaching Management at the Present Stage}

\subsection{Not Advanced Education Ideas and Concepts in Teaching Management}

At present, the scale of higher education in China has been transferred from elite education to popular education stage. College students' quality, the scale of running a school, and teaching staffs all have taken place great changes, but the management idea and the management level is still outdated. In the last few years, the backward idea of the ideological education is the main problem in the teaching reform. First of all, many of the teaching management staffs are obsolete in the management idea, who just proceed corresponding management in accordance with the rules and regulations, failing to fully stimulate and mobilize the enthusiasm of teachers and students [1-2]. The second one is that some university teaching management personnel have no deep awareness, and many teaching management cadres do not pay attention to their own work, unwilling to learn to study business, even do not pay attention to the improvement of the quality of their own. The third is that the attention paid by a lot of Colleges and universities to the teaching management team construction is not enough. All the time, the management of our country's Colleges and universities, only focuses on 
the requirements of personnel training objectives, while the development of students' personality is not paid enough attention to, which reduces the training of innovative ability. This idea not only leads to the repetition of the teaching content, but also not conducive for the students to come into contact with the forefront of science [3]. Although it takes a lot of teaching time, there is no full elaboration of the new theory. Therefore, the backwardness of the concept of ideological education has hindered the pace of the reform of teaching management.

\subsection{Inadequate Attention in Teaching Management and Undefined Purpose and Task of Teaching Management}

In the teaching management in present stage, schools and managers do not pay enough attention to the teaching management. With the rapid development of China's education, Colleges and universities in our country are also in constant expansion, and the scale of school is expanding constantly. At the same time, teaching staffs are also changed, ignoring the importance of teaching management. Teaching management staffs constantly changing results in that there appear the loopholes in management. Most schools do not treat the teaching management as a discipline that school management is not in place, which also causes the information communication of education research inside and outside the school, without organized or planned management research [4]. In consequence, in the work, they are unwilling to learn the knowledge of management. They have no idea about the management, but also do not pay attention to improvement of the quality of their own, which hinders the quality of teaching management. In recent years, the development of higher education in China is relatively fast. In the new situation of teaching management, it has also put forward new challenges, and higher requirements are proposed on the purpose and tack of teaching management. But at present, many Colleges and universities have not aware of this point, especially for the newly established Colleges and universities, the management concept and level of teaching management personnel are still stopped in the original position. The understanding is not deep enough in the purpose and task of teaching management in Colleges and universities, which impacts the improvement of the quality of teaching management.

\subsection{Lack of Innovation in Teaching Management}

At present, most of the school only stay in the conventional management work in view of teaching management work. They only maintain the normal order of the school, while ignore the scientific management of teaching. If the teaching management only maintain the current situation, while do not think about or explore new ideas and management methods, then the management road will be more and more narrow. Ignoring the innovation of teaching management ultimately will become a stumbling block of teaching management in Colleges and universities. The first reason is that the teaching content outdated phenomenon is prominent, the teaching plan lacks innovation, and students' curriculum system cannot fully reflect the latest achievements of the modern society and the development of science and technology, resulting in the classroom knowledge disjointing from social development practice. The second one is that the teaching management content is obsolete and single. Many Colleges and universities, in teaching management, too much emphasize centralized, unified and single teaching method, while fail to give enough attention to student's personality development, which weakens the cultivation of students' innovative consciousness and innovative ability.

\subsection{Centralized Power of Teaching Management and Serious Autonomy of Management}

At present, the main organization forms of our country's Colleges and universities are ranking systems mainly characterized by centralization of power, and its basic operation rules are the upper level making decision and the basic level implementing. Most of the university management work are concentrated in the hands of the teaching management department. Managers only do things according to the instructions of the superiors, without autonomy, cannot play their own subjective ability and creativity. As shown in Table 1, general Colleges and universities teaching management level often adopt hierarchy, followed by the principals, education supervisor vice president, office of academic affairs, the secondary College (Department) and so on, and work is generally being issuing instructions from top to bottom and reporting from bottom to the top [5]. The president possesses the final decision right of teaching affairs, and the dean's office assist and implement the president's 
decision, which occupies most of the decision-making and management rights of the university. On the contrary, the secondary College (Department), which is exposed to the basic level and the specific teaching management, has a relatively small power, thus causing the imbalance of power.

Table 1 Administrative institutions of Colleges and universities in China

\begin{tabular}{|c|c|c|c|}
\hline \multicolumn{2}{|c|}{ Party committee system } & \multicolumn{2}{|c|}{ Administrative system } \\
\hline $\begin{array}{l}\text { School first class } \\
\text { institutions }\end{array}$ & $\begin{array}{c}\text { School two and auxiliary } \\
\text { institutions }\end{array}$ & $\begin{array}{l}\text { School first class } \\
\text { institutions }\end{array}$ & $\begin{array}{c}\text { School two and auxiliary } \\
\text { institutions }\end{array}$ \\
\hline Party Committee Office & $\begin{array}{l}\text { Department of Party } \\
\text { Committee }\end{array}$ & Principal's Office & School Faculties or Departments \\
\hline $\begin{array}{l}\text { Commission for Discipline } \\
\text { Inspection }\end{array}$ & Subsidiary Party Committee & $\begin{array}{c}\text { Development } \\
\text { Planning } \\
\text { Department }\end{array}$ & School Research Institute \\
\hline Propaganda Department & $\begin{array}{l}\text { Research Organization } \\
\text { Party Committee }\end{array}$ & $\begin{array}{c}\text { Research } \\
\text { Department }\end{array}$ & School Affiliated Institutions \\
\hline Organization Department & Party Branch Department & $\begin{array}{c}\text { Financial } \\
\text { Department }\end{array}$ & Experimental Center \\
\hline $\begin{array}{c}\text { The United Front Work } \\
\text { Department }\end{array}$ & & Personnel Division & Archives \\
\hline Student Work Department & & Dean's Office & Library \\
\hline Party Committee & & $\begin{array}{l}\text { Students' Affairs } \\
\text { Division }\end{array}$ & $\begin{array}{c}\text { Newspaper Publishing } \\
\text { Organization }\end{array}$ \\
\hline \multirow[t]{5}{*}{$\begin{array}{c}\text { School Union } \\
\text { The School League } \\
\text { Committee }\end{array}$} & & $\begin{array}{l}\text { Graduate Student } \\
\text { Department }\end{array}$ & Information Network Center \\
\hline & & $\begin{array}{c}\text { Capital Construction } \\
\text { Department }\end{array}$ & $\begin{array}{l}\text { Primary and secondary schools, } \\
\text { kindergartens, etc. }\end{array}$ \\
\hline & & HQC & Institutions Run Industry \\
\hline & & Security Department & Life Support Agency \\
\hline & & $\begin{array}{c}\text { International } \\
\text { Cooperation and } \\
\text { Exchange }\end{array}$ & \\
\hline
\end{tabular}

As shown in Table 2, with China's Colleges enrollment expansion and consolidation, scale of Colleges and universities continuous expansion and development of the complexity of the situation of teaching management affairs, the centralized organizational structure brings more and more challenges for the teaching and management work in Colleges and universities.

Table 2 The change of the number of institutions of Colleges and universities in China

\begin{tabular}{|c|c|c|c|c|}
\hline Year & 1980 & 1992 & 2001 & 2012 \\
\hline $\begin{array}{c}\text { Average number of } \\
\text { administrative institutions }\end{array}$ & 19 & 27 & 25 & 33 \\
\hline $\begin{array}{c}\text { Average number of party } \\
\text { institutions }\end{array}$ & 7 & 9 & 7 & 6 \\
\hline
\end{tabular}

\section{Strategies of Improving Teaching Management in Colleges and Universities}

\subsection{Take Human as the Fundamental Starting Point and Change the Idea of Ideological Education}

First of all, let teachers and students participate in teaching management. The main objects of teaching management in Colleges and universities are teachers and students who are mainly engaged in academic study and research work, which has strong autonomy tendency. College teaching 
management under the new situation should also according to these characteristics. The managers should change from the past "blanket" to strengthen the guidance and service, respect the subjectivity and autonomy of object management, and attract teachers and students to participate in teaching management decision and the supervision work, for teachers and students to participate in the teaching management decision-making and supervision work, implement teachers and students participation management, and promote the teaching management in Colleges and universities more benign and efficient in operation. Secondly, we should take the students as the core and implement flexible educational system [6]. Flexible educational system can arrange teaching adapt to the student's own situation and learning requirements, and provide self-design and self-taught platform and development space for students, so as to overcome the present situation and problems in our country. In addition, the implementation of flexible educational system should consider the specific conditions of the country and the school.

\subsection{Establish a Scientific and Rational Evaluation System of Teaching Management}

Higher education mode in our country is too traditional, only cultivating students to be engaged in simple technical operation and technical application, which far adapts to today's era of knowledge economy. As a result, expecting to establish and perfect teaching management mode, and make the target management effectively operate in the work of teaching, we must start from these aspects: firstly, do the investigation and research well and determine the specific working target. According to the school's own situation and characteristics, proceed in-depth investigation and study, so as to determine their own work objectives. Secondly, implement the objectives of teaching management [7]. In the case of the objectives of the work determined, mobilize the enthusiasm of the staffs, focus on people-oriented, and input teachers' energy to the work of teaching management, as shown in Figure 1. Create reasonable College teaching evaluation system and make teaching management objectives to be achieved, improve the teaching quality and further deepen the reform of teaching.

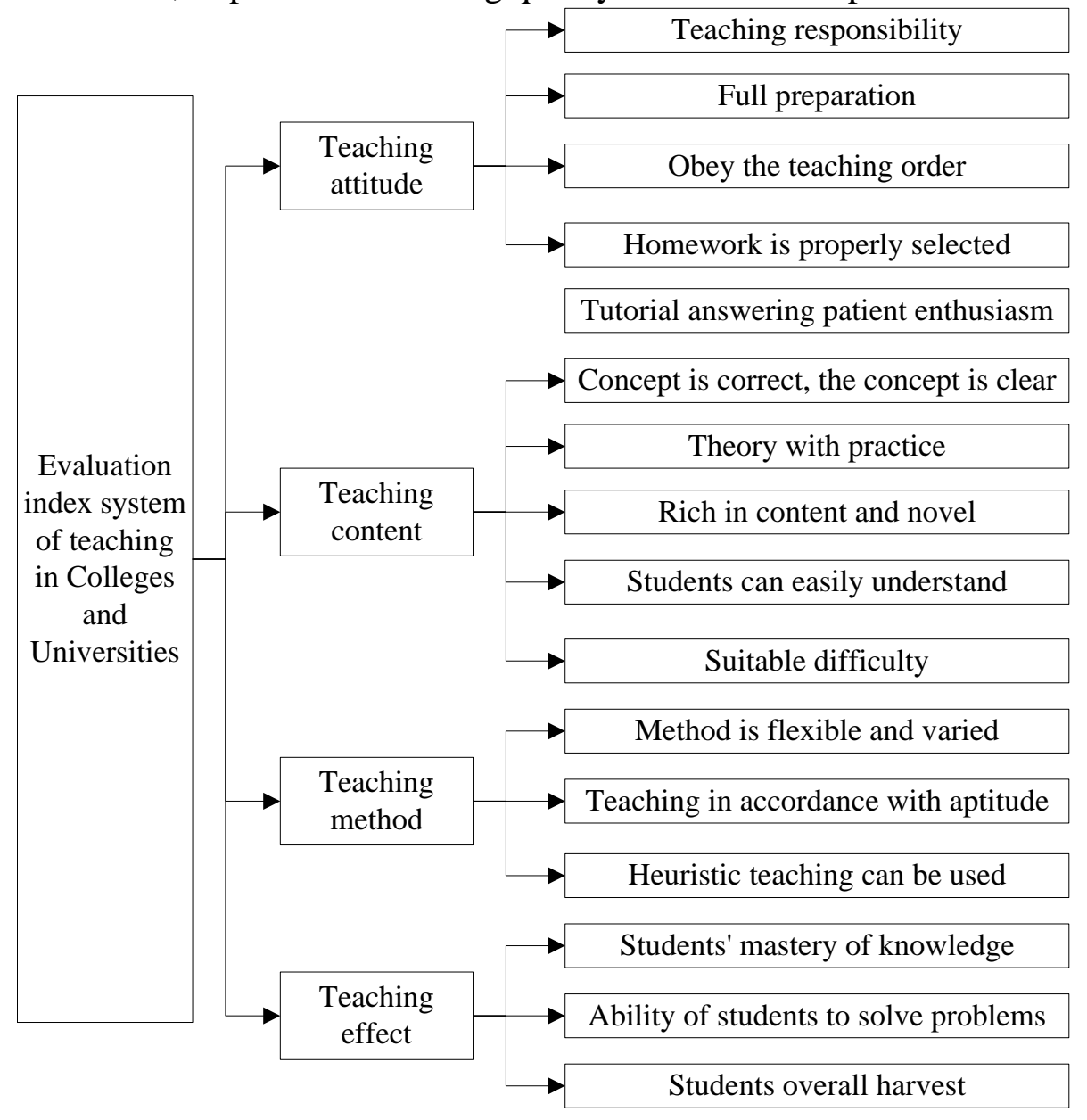

Figure 1 Evaluation system of teaching in Colleges and universities 
In teaching management work, in order to achieve the true meaning of governance, we must first of all strictly supervise President and other managers' execution of administration law. Separate academic management and administrative management, explore new teaching management system, establish rules and regulations, and strengthen academic management [8]. Secondly, we need to carry out study of the teaching quality management system in Colleges and universities: carefully study the basic theory and principle of the quality management; analyze and do research on the relationship between Colleges and universities with government and social intermediary, further obtain the subject and object and so on under new situation of teaching management system of China's Colleges and universities, as shown in Figure 2, to establish a scientific and reasonable evaluation system.

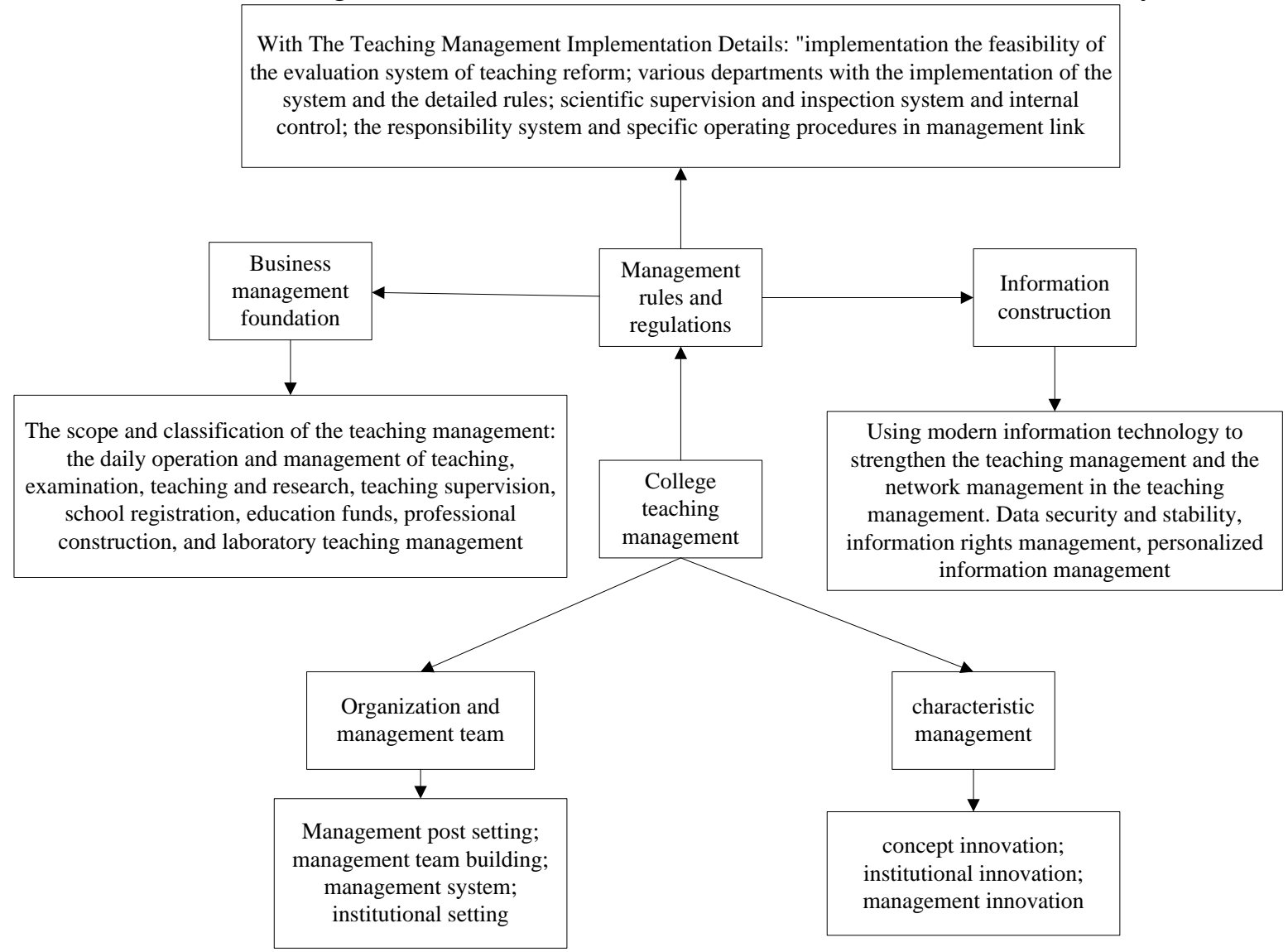

Figure 2 Teaching evaluation management system in Colleges and universities

\section{Conclusion}

Teaching management work is one of the important jobs in higher education management. At present higher education of our country is facing economic globalization, and the information technology is developing at a high speed. Under such a situation, Colleges and universities undertake the dual task. That is to cultivate talents who conform to the requirements of the state and the times, also need to meet the requirements of social development. This requires that the universities do the management of the teaching well, continue to deepen the reform of teaching management, and strive to improve the teaching quality and management level, so as to complete the historical task of quality cultivation.

\section{References}

[1] Trout A T, Cohan R H, and Ellis J H. Teaching management of contrast reactions: does it work and how often do we need to refresh [J]. Academic radiology, 2012, 19(4): 498-504.

[2] Wilbeck J, Phillippi J, Schorn M. Teaching Management of the Unexpected Birth: Application of Multimodal Techniques [J]. Advanced emergency nursing journal, 2014, 36(1): 87-96. 
[3] Chen D L, Chen L, and Ji Q F. The Experimental Teaching Based on Hybrid Cloud Management System Research[C] Applied Mechanics and Materials. Trans Tech Publications, 2013, 347: 2257-2260.

[4] Xiang L I. Exploration of teaching quality management in the practice teaching of software engineering [J]. Journal of East China Institute of Technology (Social Science), 2013, 1: 022.

[5] Wang Q, Woo H L, Quek C L. Using the Facebook group as a learning management system: An exploratory study [J]. British Journal of Educational Technology, 2012, 43(3): 428-438.

[6] Qu A. Study and design of college education and teaching management system based on Web Technology [J]. Electronic Test, 2014, 20: 10-12.

[7] Blais K. Professional nursing practice: Concepts and perspectives [M]. Pearson, 2015.

[8] Tserendorj N, Tudevdagva U, Heller A. Integration of Learning Management System into University-level Teaching and Learning [M]. Techn. Univ., Fak. für Informatik, 2013. 